\title{
In Recognition of the Abyssinian General
}

\author{
Robbie Shilliam
}

I am an Abyssinian General. These are my troops. Do not cross this bridge. You see me lying down with cutlass in my hand? I will cut you if you cross. No plantation work at Lusignan today. Or tomorrow. Not here, nor anywhere in Demerara. Don't try send the Indian workers. They won't cross either. For we are at war. With Italy. And with you.

Over wages? Well, true, we always agitate around this time of year, after crop over. And true, this year we yielded high with the sugar so our wages are bound to be even lower. But don't call it a strike. I told you. Can't you hear the drums? This is war. And see this red flag? That is our flag. No hammer and sickle. The red flag of Africa. This year is the year of salvation and of our liberation.

We heard the district commissioner say that we had an extraordinary idea of the relationship between Britain and Abyssinia. They can't fool us. We know that even the Governor is shook up. He worries that our mind has been most powerfully affected by our war with Italy. That we are seeing the world situation here and there through the lens of colour. And he is right. The 100 extra police sent from Georgetown will not be enough to quell this fire.

This is not a bondsman, nor a slave descendent, but an Abyssinian general. How the descendent of an enslaved African became an Abyssinian general is a mystery to the slavemaster/massa/governor/lord. It is certainly not a reasonable transformation; and more distressingly, it seems to have been pursued out of sight of massa. Perhaps it has been happening behind the provision grounds communally at night. On the wings of a song that traverses the hinterlands of the spiritual realms wherein no ocean could block the pass. This General is not concerned as to whether the Governor of British Guyana recognizes him as 
such or as a deluded and impressionable black who has mistaken the English for Italians. (Perhaps it is a communist conspiracy.) Regardless, the Abyssinian general will pursue African liberation at home and abroad.

The Abyssinian general is not recognized, nor is he misrecognized. He is unrecognizable to massa. Recognition theory, predominantly ensconced in debates over the prospects and pathologies of the European modern self, stumbles when it comes to engaging with the radical un-recognition that is congenital to the reproduction of colonial difference and perhaps at its most extreme in the slave plantation archipelago of the Americas (and elsewhere too). However, enslaved Africans and their descendants have struggled to maintain and cultivate practices of recognition that work autonomously to - if always in confrontation with massa and his European episteme. In this chapter we will journey from colonial recognition towards a recognition of the Abyssinian general that is other-wise.

Hegel's The Phenomenology of Spirit (1977) prepares the student to grapple with his system of Logic (1975) by positing that the dialectic between consciousness and self-consciousness is a necessary existential as well as philosophical pursuit. Does it prepare the student to recognize the Abyssinian general?

Over a number of different sections of The Phenomenology, Hegel replays the seemingly ceaseless movement to realize self-consciousness in the world, that is, to be in-and-for oneself by relating to other self-consciousnesses inand-for-themselves. Two entities start by recognizing themselves as other selfconsciousnesses in a state of radical equality: 'each sees the other do the same as it does; each does itself what it demands of the other, and therefore also does what it does only in so far as the other does the same' (Hegel 1977: 112). Hence, each entity is the 'middle term' for the other: I am for myself, but I am also for another. Through the middle term these self-consciousnesses 'recognize themselves as mutually recognizing one another' (Hegel 1977: 112).

But the moment where this manifestation of Geist takes on the form of direct political struggle is in the showdown between the Herr and Knecht - the lord and bondsman. And with the entrance onto the stage of these two personalities an inequality splits the middle term up into two extremes. The lord only recognizes, the bondsman is only recognized (Hegel 1977: 112-13). The lord is an independent consciousness 'whose essential nature is to be for itself', while the bondsman is a dependent consciousness 'whose essential nature is simply to live or to be for another' (Hegel 1977: 115). Hegel does not explain the provenance of this sudden inequality that is injected into the dialectical unfolding of Geist. 
Nonetheless, Hegel proceeds to script a life and death struggle between lord and bondsman to be recognized as an independent self-consciousness.

In this struggle death can hold no resolution, not even the death of the bondsman for the lord. For death will collapse the middle term into a 'lifeless unity' rendering both entities mere things. Alternatively, Hegel insists that recognition is key to self-consciousness, even that of the lord. So although the lord might recognize the bondsman only as a thing, it is still a thin recognition: the lord is essential only because the bondsman is unessential (Hegel 1977: 116). Alternatively, Hegel considers the bondsman to have an independent existence even if only in terms of thinghood. In fact, the experience of sheer negation has filled this bondsman with the dread of losing her being. So she must retrieve her self-consciousness. And rather than death, it is her service to the lord through work which will provide an alternative route to shape this thing that is her entity. Through fear and service she recognizes herself again, indeed, she becomes even more self-conscious of her own agency (Hegel 1977: 118).

At this point the lord and bondsman disappear from view in Hegel's text, hardly to be heard of again (Buck-Morss 2000: 848). They have appeared suddenly and they disappear just as suddenly. The reader might be left wondering: was reconciliation achieved between the two? A more surreptitious reader might also question, of what use for the dialectic is the lord, now that the bondsman has liberated her own self-consciousness in a way that the lord could not? Perhaps it is only the bondsmen who, through their lived experience, are able to dialectically arrive at being in-and-for their selves through relating to other self-consciousnesses in-and-for-themselves...

Susan Buck-Morss (2000) suggests that the appearance of the lord and bondsman is prompted by reports of the Haitian Revolution which appear in Minerva, a journal that Hegel reads. Sybille Fischer (2004: 24-33) suggests that the disappearance of the lord and bondsman might be something to do with the resolution of the Haitian Revolution in 1804. Michel-Rolph Trouillot (1995) points out that this triumph of the enslaved was a resolution to the life/ death struggle that European philosophy had no framework through which to comprehend. The Haitian constitution of 1805 announced in Article 2 that slavery was forever abolished; neither the American nor French Declarations had dared to progress the struggle for recognition to that extreme. And yet European Enlightenment thought did not engage with enslaved Africans except as 'slaves', that is, as humans in biology only. Africans were regarded as tragically devoid of reason and agency, especially what Hegel would call 'worldhistorical' agency. 
Hegel's silence on the fate of the enslaved is one note in a chorus of oblivion that structures the majority of European Enlightenment thought on rights and recognition. This chord strikes an epistemic silence on behalf of colonial difference and is played in almost every enlightenment Psalm (see Shilliam 2013a). In these texts, discussions of rights are usually made through speculative reason and recourse to natural law. And in these discussions, humanity is assumed and hence rights discourses are, within their abstract parameters, universalistic. However, substantive investigations of the composition of humanity - and who is deemed to be competently human - are usually made separately to rights discourses via anthropological and/or historical treatises or even through practical considerations on imperial administration. There, the competencies required to be human are delineated on the spurious grounds of race and culture.

Via this division of labour the universal impulse of rights and recognition can avoid crashing into the partial and discriminatory framing of who is to be included as competently human. So for example, Locke's Two Treatises can affirm the inherent equality and freedom of human beings under natural law, that is, the impossibility of justifying slavery; yet, in his drafts of the slave Constitution of Carolina Locke can categorically state that slave-owners can hold Negro slaves in utter dominion with no hope of salvation (see Farr 2008). Kant can argue for categorical imperatives that are universally binding in terms of conduct. He can even apply this to peace treaties and diplomacy in ways that, in principle, demonstrate an anti-colonial ethos of recognition across difference (see Jahn 2005). Yet in his anthropological work, Kant can separately set out the basic competencies of being human. He does so by utilizing racist travelogues that allow him to segregate peoples who have the potential to appreciate the sublime and the beautiful from those who have no such faculty, or can only feel for the grotesque (Eze 1997; Shilliam 2011; on aesthetics and colonial difference see Mignolo and Vazquez 2013).

We can situate Hegel in the same flow of colonial mentality. His Phenomenology and Philosophy of Right make speculative reason work critically on the matter of family, civil society, religion, state and world history through the recognition process, that is, the becoming of self-consciousness. Yet in his Philosophies of History, as is well known, Hegel judges Asia to be lacking in the cultural competency to move with the dialectic, and he completely disavows Africa as unable even to enter such a process (Guha 2002; Lockward 2006; Taiwo 1997). This is perhaps why the passage on the lord and bondsman is so telling. To follow his own logic, Hegel would have to follow Geist, the World Spirit, to 
Haiti, populated by Negros who, although winning their freedom in thought and action, should not even be standing on the world-historical stage. In those few passages that follow the lord and bondsman, the colonial difference is suddenly revealed in the kinetic energy discharged when speculative reason, recognition and racism briefly collide.

Inspired by the Negritude movement in Martinique and dismayed by his racist experiences while studying psychiatry in metropolitan France, Frantz Fanon dwells on this collision. In fact, he situates his critique of recognition directly within the silent yet explosive space of colonial difference. In his major treatise on the subject, Black Skin White Masks, Fanon partly mirrors Hegel's method in the Phenomenology of consistently working through the strivings and failures of self-consciousness to actualize itself. Fanon also, in a Hegelian fashion, duplicates himself as the voice of the text - that is, the consciousness that is experiencing the process - as well as the theorist of this experience (Gordon 2005: 4). But Fanon radically differs from Hegel in making race and colonial difference the starting point of both experience and theory. And unlike Hegel he does not segregate speculative reasoning on recognition from anthropological delineations of the competencies of human being.

Fanon (2008: 10) announces this confrontation by declaring, at the start of his text, that 'the black is not a man'; what appears, instead of a man, is a 'zone of non-being. And, exposing Kant's prejudice, Fanon (2008: 44-5) argues that racial difference provides for a 'genuinely Manichean concept of the world' wherein white is beauty and the precision of definition, while black is a fusion with the world and an abandonment of ego. Crucially, Fanon's starting point, unlike that of Hegel's, is not that of radical ontological equality. Rather, a human faces an un-human - a presence faces non-being (see Kleinberg 2003: 116, 121; Honenberger 2007: 158). From this starting point there can be no dialectical pathway available to cultivate mutual recognition (Oliver 2001: 23). The white does not 'see another do the same as he does' (Hegel 1977: 112) because he does not recognize that the thing facing him is a fellow self-consciousness. As Kelly Oliver (2001:3-9) puts it, Fanon proposes that the black cannot even experience the privilege of alienation because there is no confrontation between selfconsciousnesses - even unequally positioned ones.

What is more, although each colour is 'sealed into his own peculiarity', Fanon (2008: 44-5) states that black being is fundamentally comparative. So contra Hegel's schema of ontological equivalence, the black cannot be an individual 
(Fanon 2008: 211). As a non-being, the black must compare itself to a humanity colonized by whiteness (Fanon 2008: 110). Conversely, the white has no need to reciprocate such an anxiety. By these terms, in order to become an individual with self-consciousness, the black must somehow become white (Gibson 2002: 31 ). Hegel never considers this kind of transmogrification, argues Fanon (2008: 63), a process that would require recognition to be pursued intergenerationally through miscegenation and self-erasure - 'passing' (also, to die). In this respect, colonial difference outlaws the ontological basis of reciprocity: they are not both human beings, and so the bondsman has no independence even in bondage as Hegel assumes (Fanon 2008: 169). The master laughs at the 'consciousness' of slaves. He does not require recognition from them; that would make no sense, because they are non-beings. Instead, the master simply demands work (even unto death) (Fanon 2008: 172).

Confronting the problem of recognition in the intimate presence of colonial difference articulated through race, Fanon's project is less concerned with mutuality between lord and bondsman and much more focused on practices of self-meaning and self-valuation undertaken by the bondsman. That is, the challenge for the bondsman is not so much disalienation in terms of reconciling individual self-consciousnesses to each other, but more so disalienation as a process of collective rehumanization (Coulthard 2007: 453-4; Oliver 2001: 29). (This is a necessarily collective process as individuality is outlawed by racist racialization.) In Hegel's colonial schema this project would appear as 'negativity', that is, a turning away from relationality and the movement of Geist. Yet this assumption is precisely what Fanon brings Jean-Paul Sartre to task for. Sartre appraises Negritude as a transient antithetical moment on the way to a preordained synthesis of European humanism. But, Fanon (2008: 133-4) remarks, 'that born Hegelian had forgotten that consciousness has to lose itself in the night of the absolute, the only condition to attain to consciousness of self'.

Speaking to the challenge of indigenous self-determination in Canada, Glen Coulthard (2007: 454) argues that Fanon's critique of Hegel requires the colonized to re-evaluate their own histories. And it is here that I would suggest that Fanon's decolonial episteme falls short. For Fanon is surprisingly receptive to the 'fatal impact' thesis of colonial lore, which proposes that no indigenous culture can survive the colonial encounter (Moorhead 1987). While often mobilized as a narrative frame for South Pacific colonial histories, I would argue that this thesis is clearly evident in assessments of the fatal impact of enslavement on Africans. Indeed, the vast majority of the most committed white abolitionists still presumed that these bondsmen had been stripped to the bone of all social 
and cultural competencies. All that remained was a 'negro', that is, a blank body requiring social and cultural fulfilment by European lords.

Fanon seems to have internalized the fatal impact thesis, especially in terms of his Martiniquean provenance. Famously, Fanon asks what is left of dialectical selfdetermination if the lord simply gives the bondsman - the thing - her freedom without even a struggle? Fanon is here alluding to the gift of emancipation provided by Victor Schœlcher (president of the metropolitan Commission for the Abolition of Slavery) to enslaved Antilleans in 1848. But we should contrast this settlement to that provided by the Haitian Revolution wherein the enslaved utilized the martial, political, social and spiritual skills that approximately two thirds of them had learnt in the Kingdom of Kongo to eventually clear the island of its white lords (see in general Thornton 1998). The oath sworn at the inaugurating meeting of the Revolution at Bois Caïman in 1791 was freedom or death (death being life again). So we find that in this French colony enslaved Africans were most certainly involved in a deadly struggle for freedom (BuckMorss 2000: 848). Moreover, no blank bodies were involved in this dialectical moment - they came with African matter to fertilize the soil of St Domingue long before the revolution. It is even the case that Martinique itself witnessed revolts and rebellions just before, during and just after the Haitian Revolution (Geggus 1996). The whole of the Caribbean was in ferment, of course.

It is, then, somewhat alarming to find that Fanon effectively quarantines the Haitian Revolution to the realms of colonial unbelief, where Hegel himself had consigned it. In its place, Fanon carries with him the defeat of the enslaved in Martinique by Napoleonic forces and the concomitant re-introduction of slavery. Even these doomed struggles disappear in Black Skins when Schœlcher, the white lord, changes his heart in 1848 and proposes to his colleagues, 'let's be nice to the niggers' (Fanon 2008: 222). What is more, in his concluding chapter Fanon (2008: 226) seems to partially disavow inheritance of the Revolution when he proclaims that 'I am a man, and what I have to recapture is the whole past of the world. I am not responsible solely for the revolt in Santo Domingo. We must place this somewhat anxious statement within Fanon's engagement with Negritude. Fanon, Bernasconi argues, might here be endorsing fellow Antillean Aimé Césaire's apprehension of a blackness routed through struggle, yet disavowing the continental version of Negritude expressed by Alioune Diop and Léopold Sédar Senghor wherein blackness is rooted in an African soul (see Bernasconi 2002).

Accepting the fatal impact thesis, Fanon is wary of consigning black agency to an African past that, for him, no longer lives, and so he treats any claims to an African identity/soul with great suspicion. Indeed, these souls are not authentic 
for Fanon but merely by-products of the segregating logic of colonial rule. In short, the very notion of African identity/soul is framed by whiteness already (Bernasconi 2002: 72-3; Fanon 2008: 186). And because he is trying to escape from such whiteness, Fanon (2008: 226) implicitly substitutes the African pasts active at Bois Caïman for a focus on creating a brand new humanism.

In his later writings, Fanon (1968: 57) does turn back to those traditions utilized at Bois Caïman, whereby, in the protective and permissive drum circles, the dehumanized allow themselves to be possessed by the ancestral spirits, lose their limits and animate themselves so as to embark upon an exorcism of colonialism. Nevertheless, Fanon treats these 'traditions' instrumentally. Keen to escape the dialectical traps laid down by the lord/massa, Fanon cannot consider the drum beats as aspects of living knowledge traditions. Indeed, we should not forget that for Fanon drums are the ultimate fetish that white people have used to entrap him in an unhuman blackness, a zone of non-being:

I was responsible at the same time for my body, for my race, for my ancestors.

I subjected myself to an objective examination, I discovered my blackness, my ethnic characteristics; and I was battered down by tom-toms, cannibalism, intellectual deficiency, fetishism, racial defects, slave-ships. (Fanon 2008: 112)

Hence Fanon believes that what is being played out on the tom-toms are merely internalized reactions to the violence of colonial rule. Such reactions have no epistemic validity, although the pulse of the drum might somehow kinetically charge a movement to forge brand new futures.

In sum, Fanon radically repositions Hegel's dialectic of recognition so as to confront the colonial difference - to move to the impossible place where the discriminatory delineation of humanity coincides with the speculative claims of universal right. To escape from this impossible condition the colonized must turn inwards, into the night of the absolute, in order, precisely, to reclaim their universality and humanity. However, Fanon effectively sanctions Hegel's silence on Haiti, and with that, implicitly endorses (or at least does not substantively refute) Hegel's narrative of world history that leaves Africa and Africans as prehistory. Turning inwards there is nothing to be found worthy of preservation. A surreptitious reader might ask this: so with what creative matter (not generic instrumental energy) would it be possible to cultivate a new humanism - not the thin particular of European philosophy that masquerades as a universal, but a thick decolonized humanism?

Fanon could have the answer to his own problem and it lies in dispensing with the fatal impact thesis. At the start of the concluding chapter of Black Skins, and 
announcing the anti-colonialism of The Wretched of the Earth, Fanon washes his hands of the Antillean intellectual who, he argues, wilfully seeks to become alienated through an intimate relationship with European culture. In contrast, the 'Negro laborer building the port facilities in Abidjan' is being exploited by a colonial authority that holds his humanity in contempt (Fanon 2008: 223-4). Fanon then relates a correspondence between this Negro labourer, one who does not even enjoy alienation, to one working on the sugar plantations of Martinique and admits that 'it would never occur to me to ask these Negroes to change their conception of history' (Fanon 2008: 224). Indeed, of the 'few workingclass people' whom he knows in Paris, Fanon notes that they never posed the problem of discovering a 'Negro past' precisely because 'they knew they were black' (Fanon 2008: 224). Fanon does not ask, what is the provenance of this blackness that they knew?

I am an Abyssinian general. I must do my part in the collective struggle for African liberation - here in the plantations of Americas and in the highlands of Ethiopia. I have the Africa flag and African drums. They are my compass and my energy store.

Was there a High John de Conquer in Martinique that Fanon did not know about? Zora Neale Hurston, famous African American anthropologist and relater of African American folk lore, reveals the existence of High John to the white North American public just as the United States enters the Second World War. It is a moment where even white people need something to believe in.

High John was a mighty man, but not a normal man. He was first a whisper, a 'will to hope', 'a wish to find something worthy of laughter and song' (Hurston 1995: 922). He became flesh and walked in rhythm, 'as if the world he walked on was a singing-drum' (Hurston 1995: 922). You could tell High John was present through his laugh and his drum beat. He had come from Africa, travelling to the Americas 'on the waves of sound' and on the winds that filled the sails of the slaving ships (Hurston 1995: 923). High John de Conquer provided for the enslaved 'an inside thing to live by'.

The slave master could not understand this precious thing: 'in an outside way, [slavery] was old massa's fun, so what was old cuffy laughing for?' High John fought pitched battles 'without outside-showing force', winning wars from within, for the liberation of the souls of black folk: 'He who wins from within is 
in the "Be" class. Be here when the ruthless man comes, and be here when he is gone' (Hurston 1995: 924). On the plantation, old John could beat unbeatable odds. Occasionally, massa would win, but even then High John could avoid a terrible fate and massa would have to laugh at that too. High John would even force upon massa 'a sort of recognition that life is not one-sided... [and that] we are just as ridiculous as anybody else' (Hurston 1995: 927).

But most importantly High John told his enslaved people that they had to find a song that would carry them through to liberation and beyond. He took them on a journey through spiritual hinterlands, to hell and heaven and finally to the workshop of the Old Maker who crafted for them their own tune. A wordless tune, hence, one that 'you could bend and shape in most any way you wanted to fit the words and feelings that you had' (Hurston 1995: 929). And that became the freedom song which drove the struggle forward. After emancipation, High John de Conquer went back into mystery, travelled back to Africa, but left a root of his power in the soil of the Americas, so as to be summoned again when needed. Aunt Shady Anne Sutton, who recounted to Hurston these memories of High John, was wary of people like her niece who had gone north to pursue an anthropological education:

I hope you ain't one of these here smart colored folks that done got so they don't believe nothing, and come here questioning me so you can have something to poke fun at. Done got shamed of the things that brought us through. (Hurston 1995: 925)

Shame might force you to embrace the pseudo comfort of a fatal impact thesis. Worse still, shame might even make you misrecognize Hegel's racist Geist as a friendly spirit that could guide you to a dialectical 'turning point' where your selfconsciousness would leave behind 'the colorful show of the sensuous here and now and the nightlike void of the supersensible beyond' (Hegel 1977: 110-11). Leaving behind High John de Conquer. Only then would Geist be able to deliver you to the 'spiritual daylight of the present' (Hegel 1977: 111), a daylight illuminated by another self-consciousness that stands in front of you in reciprocity. You, however, will be confronted with massa, with un-recognition of your humanity, with no basis for reciprocity to begin the process of dialectical illumination. Then you will stand in the spiritual darkness of the present, as a zombie, wondering how you might ever become enlivened to repossess yourself and your communality. Geist will desert you. And massa will utterly control the manifest world. Perhaps he might allow you a slender escape to an afterlife. An afterlife that he nevertheless guards the gates to, as testified by this old song from Antigua: 
massa say if I serve him when I die

a gonna go to heaven when I die

serve him at the very best

heaven me portion when I die

wo, wo, wo, wo

heaven me portion when I die. (Smith and Smith 1986: 88)

You would be in dire need of navigation.

High John shines spiritual nightlight on your present condition. He guides you to creatively retrieve the agency that came with you from Africa so long ago for the redemption of your collective self in the here and now. In the absolute nightlight you might glean agencies that dwell in places that could never be enslaved, that is, in the spiritual hinterlands.

Erna Brodber (1997: 98) calls this mode of reclaiming - re-recognizing - your collective self as 'the hegemony of the spirit'. And she terms the methodology for such retrieval as 'celestial ethnography' (Brodber 1997: 61). A cartographic practice too, no doubt. Brodber expounds this methodology in the novel, Louisiana, which she conceived as a lecture to peoples of African Caribbean and African American heritages on their long history of cooperation (Brodber 2012: 123). It is fundamentally the story of three women of black consciousness, two - Anna and Lowly - who have passed to the spirit realm, one - Ella who is in the manifest realm. Brodber intentionally models Ella as a carrier of Hurston's legacy - an African American anthropologist (albeit born in Jamaica to Jamaican parents) who is paid to go into the field, the Black South - with a big tape recorder, and who ends up retrieving less the data to feed white theory and more the black matter for redeeming collective self (Brodber 1997: 125).

Ella has been instructed to extract a life history from Anna, the Southern matriarch, but it does not go well. At the end of her first session Anna has given her little of substance, 'one whole side [of the tape] gone', ponders Ella, 'and not a thing to give to the white people' (Brodber 1997: 21). Tragedy strikes when Anna passes before Ella has the opportunity for further interrogation. Yet at the funeral, a strange thing happens. Ella loses herself and although she cannot remember doing it subsequently, utters 'ah who sey Sammy dead?' A voice speaks to her, familiar but not of her immediate relatives: 'the ears are hearing other frequencies. The child has come through. Anna, she'll make it' (Brodber 1997: 28). Later, Ella realizes what experience she has undergone:

There is a name for that state in which your body is depressed into physical collapse and something else is activated, rather like an injection needle is pushed 
forward and the shell in which it resides recedes. 'Getting over'. I prefer to call it hegemony of the spirit. (Brodber 1997: 98)

From this point Anna, her Jamaican friend Lowly (who had affirmed that the child had come through) and Ella are bonded in a 'celestial ethnography' (Brodber 1997: 61). As Ella replays the tape recorder the voices of Anna and Lowly progressively reveal to Ella a history of struggle. Anna, it turns out, is born into a family culture that has been defined through 'punished resistance', and she carries on this tradition as a Garveyite, a black nationalist organizer of the South in the early twentieth century.

The celestial sisters regularly announce their forthcoming presence to Ella by whispering the modified line of a song, the line that Ella uttered at Anna's funeral. This Jamaican folk song is entitled 'Sammy Dead Oh' and was re-popularized in the 1960s (Brodber 1985). The song tells of how Sammy grows a crop and is killed by his envious neighbours. There is a spiritual wickedness to his death; a suggestion that Sammy's neighbours used Obeah (science) to unnaturally kill him and in so doing release a restless spirit. Through Ella, Brodber turns the refrain around: ah who say Sammy dead? Sammy has been redeemed and his spirit is at rest (Sharpe 2012: 96). Remember, High John de Conquer says that you can put any lyrics into the freedom song, so long as you make it yours and turn it towards emancipation. And Ella has realized that this skill of 'turning' is her vocation:

Stand if you will. Let your arms hang loose in front of you. Now put the tips of your index fingers and the tips of your thumbs together. Your extremities now form a diamond. Imagine the diamond to be solid three dimensional. Now pierce a hole through the center of this. That hole, that passage is me. I am the link between the shores washed by the Caribbean sea, a hole, yet I am what joins your left hand to your right. I join the world of the living and the world of the spirits. I join the past with the present. In me Louise [Lowly] and Sue Ann [Anna] are joined... I am Louisiana. (Brodber 1997: 124)

Ella has become the 'kind of historian who gives the ordinary people their history' (Brodber 2012: 123). This vocation might well have shamed her Jamaican parents, if they were to see it (Brodber 1997: 31). And massa's halls of learning back in Columbia University cannot fathom this kind of knowledge cultivation. When Ella returns the tape recorder, years after her process of edification and transcription, she realizes that 'for this world that I had once inhabited and had to leave, I was mad' (Brodber 1997: 133). In any case, the story that Ella retrieves from the venerable sisters is not much more than what was already known by the anthropology professors of Columbia (Brodber 1997: 153). Yet the extraction of 
data is not the point of celestial ethnography; it is rather to cultivate a retrieval of collective personhood from spiritual resources - from the waters of the inside, where the outside is a desert. As Ella herself finally passes, she gushes forth 'one sound. From one body. A community song. And her husband, Reuben, recounts the meaning of Ella's life: '[Anna] would not tell the President nor his men her tale for it was not hers; she was no hero. It was a tale of cooperative action; it was a community tale. We made it happen' (Brodber 1997: 161).

Part of Brodber's fascination with Louisiana is to do with 'how people who have never met each other can walk similar paths'. This is the phenomenon that Louisiana (Lowly-Anna - African Jamaican and African American) invokes. Is this evidence of a collective unconsciousness? ponders Brodber (2012: 125). In consideration, she invokes Jung (Brodber 2012: 125). And so does Fanon. Yet for Fanon, Jung's work is shot through with racist colonial stereotypes, especially that of the uncivilized savage, 'the negro who slumbers in every white man' (Fanon 2008: 187). Jung locates this unconsciousness in 'inherited cerebral matter', but Fanon (2008: 188) counters that it is 'purely and simply the sum of prejudices, myths, collective attitudes of a given group. For Fanon, then, the collective unconsciousness is purely massa's domain.

Fanon cannot have heard of High John de Conquer. No one played old John's drum to his ear, nor taught him that freedom song. Fanon was never armed with a methodology - a compass - with which to navigate the absolute nightlight and travel through the spiritual hinterlands. The French halls of learning refused him that; all they offered was the thin pathway of Geist, which he nevertheless refused to follow. But still, he must have heard at least a whisper. After all, how could he have been so confident in saying yes to life and love in the face of the deathly dialectic of Hegel and massa (Fanon 2008: 222)? Where did that matter come from, Frantz? I think that even without possession of a celestial ethnography you still did your best to practice the hegemony of spirit. So I tell this story of the Abyssinian general as testimony to your great spirit my bredrin.

We are walking similar paths. I am singing and chanting.

... Ithiopians the tyrants are falling

Who smote thee upon thy knees

The children are lovingly calling

From over Jah distant seas... 
It was not that massa was ever unaware of the spiritual hinterlands; indeed, he regularly tried to ban the sciences that allowed for 'getting over' there. In fact massa made getting over a crime by gathering all diverse practices - some of which were only for individual gain, others of which were for collective healing into the category of Obeah (see Stewart 2004). Special attention, in this respect, was given to the African faiths that focused upon the spiritual agency known as Water Mamma. Here is evidence of an emphasis on spiritual mediumship that actively guides the living. In many West and Central African cosmologies, rivers are powerful places that intersect the human and spirit worlds to form 'aquatic temples' (Zahan 1983: 20-1; Van Stipriaan 2005). The (usually feminine) spirits of the waterways are powerful agents of intercession. High John can be accessed through many natural elements, it seems.

What is more, the numerous African renditions of Christianity that pepper the Caribbean islands share key similarities with these non-Christian African cosmologies. Baptism might be the quintessential act of colonial enculturation, denoting re-birth into the new (white) family of Christ. Yet many enslaved priests of the enslaved saw in this the continuation of what they knew already from African cosmologies, that is, the significance of water as a medium of transmission between the profane and sublime realms. Pentecost, the speaking in tongues, was just another word for the practice of channeling the spiritual agencies and ancestors, a well-established tradition in many African faiths. (Was this not the directive whispering of High John de Conquer?) And Exodus, that quintessential story of deliverance: was that not their story of African redemption? Was this not the hope that old John had brought with him now being returned? Psalms 68:31 told them so directly; gave them a compass bearing: princes and princesses must come out of Egypt, Ethiopia shall soon stretch forth her hands unto Jah. Well, they knew that they were Ethiopians because Jeremiah had proclaimed as much: a leopard could not change his spots nor an Ethiopian her skin (see Shepperson 1953; Shilliam 2013a).

Armed with such compass and energy store, you would be able to subvert and step over the American lands of the zombie wherein you could only be recognized as living dead. To re-recognize your own personhood communally, you would journey to the spiritual hinterlands and cultivate your politics of recognition there.

At the annual meal for loa (spiritual agents) in Haitian Vodou, a long litany is recited that invites the ancestors of all nations without exception to attend (Larose 1977: 103). A diplomatic gesture. While at comparable meetings in the Kumina faith of Jamaica, whites cannot ask the Bongo (Kongo) ancestors for 
help, but Indians and Chinese can join in the Kumina 'bans' (groups) (Stewart 2004: 147). In Guyana Comfa, the Heights is composed of the angels, biblical prophets and apostles; the centre of the universe is inhabited by manifest humans; and the terrestrial realms is traversed by the spirits of discarnate souls, including representatives of the Africans, Surinam Africans ('Dutch'), Indians, Chinese, Amerindians, English and Spanish, all of whom are enfolded into the global architecture of colonial rule, and all of whom are variously entreated with their own songs during ceremonies (Gibson 2005: 209-10). Members of the Converted, an African Baptist faith from St Vincent, practice a form of spiritual journeying through which they will receive guidance for problems that plague their everyday life. In this journeying they also might visit Africa, India and China - originating places of the various labourers brought to the islands by British colonialism. They might also meet Ethiopians, 'a tribe of very small, eery dark people in Africa'; although to enjoy this encounter the sojourner must have a 'tone [that is] deep in the Spirit' (Zane 1999: 85, 137; Stewart 2004: 147).

The 1823 Demerara uprising of enslaved peoples in Guyana announced the introduction of Biblical narratives into the faith systems that propelled the liberation struggle. Famously, John Smith - a member of the London Missionary Society - was accused of aiding the enslaved on the east coast of Demerara by teaching them the Exodus narrative. Smith was tried, found guilty and sentenced to death. Dying of consumption in custody instead, he became the 'Demerara martyr' (Smith 1976: 321-3). Nevertheless, the enslaved that Smith taught were not empty vessels waiting to be filled. They carefully and considerately took from these teachings of the martyr what they already knew and what was useful to them in their ongoing 'inside' struggle for recognition, the results of which were, at the right time, to be made known 'outside' (see Titus 2002).

After the Demerara uprising many enslaved Africans took the Biblical narrative with them as they turned away from white churches that seemed to be hand in glove with massa and headed back to the spiritual hinterlands, there to plant the Bible. In Guyana, Obeah practices - that is, night time meetings accompanied by drumming, chanting and dancing - were regularly outlawed during the nineteenth and early twentieth century. And the most (in)famous of these was Comfa. Comfa works in a non-dualistic universe where the material and spiritual, living and ancestors are related. Many practitioners have also been practicing Baptists, and over time a number of Comfa articles of faith have come to be justified through biblical narratives (Gibson 2001: 17).

Into this historical context stepped the Jordanites (see in general Bisnauth 1996: 180-4; Roback 1974). Joseph Maclaren was an Anglican Grenadian 
working in Trinidad in the latter part of the nineteenth century. Introduced by his friend Bhagwan Das to Hinduism, Maclaren also underwent a 'baptism by immersion. His disciple, a Barbadian man called Bowen, migrated to Guyana and there undertook a proselytizing mission, baptizing members into his 'church'. One such member was Nathaniel Jordan, a cane field labourer from whom the faith derives its name. The Jordanite Baptist faith had already been prepared by Comfa and the popularity of Water Mama. Indeed, the Jordanites place great emphasis on full immersion baptism as well as spiritual mediumship for communicating with ancestors.

Upon Jordan's passing, Elder James Klein picked up the leadership. But aside from being a Jordanite Klein was also a member of the Guyana chapter of Marcus Garvey's Universal Negro Improvement Association (Westmaas and de Barros 2011). That there would be strong resonances between both groups is not a surprise. Jordanites are adamant that their God is black and that Jesus had African ancestry. This knowledge concurred with Garvey's own theological premise, a critique of Hegel's racist Geist, that, while God has no colour, Africans must worship the Most High through the lens of one's own self-image, that is, through the 'spectacles of Ethiopia' (Garvey 1967: 34, vol.1). In the 1920s both the Jordanites and Garveyites were accused by colonial authorities of spreading a seditious messages of 'race hatred' against whites (Hill 2011: clxvii). (Massa must have thought that those spectacles were doing Obeah work.) Later, when the Italy-Ethiopia war began in October 1935, both organizations cooperated to agitate for Ethiopia's defence. It was most probably the Jordanites and Garveyites who organized meetings to petition King George $\mathrm{V}$ for their members to be allowed to fight on behalf of Haile Selassie I (Weisbord 1970: 34-5).

The Jordanites were not only strong in greater Georgetown but also along the east bank of Demerara, the rural area where, from October 1935 onwards, a series of uprisings commenced on plantations. As the Governor of Guyana noted, while unrest amongst rural workers around cropping time was not unusual, in 1935 the low price of crops had combined with a 'very strong sympathy which the blacks have for Abyssinia as against Italy' (Governor of British Guiana 1935a: 2). This had led, reckoned the Governor, to a 'new feature' whereby 'combinations' of black villagers had entered the estates and prevented mostly Indian labourers from working (Governor of British Guiana 1935a: 2-3). The intensity of the uprisings led the Governor to approve the temporary enlistment of one hundred extra police (Governor of British Guiana 1935b). Additionally, the Governor requested all District Commissioners to relay the message to their local populations that Great Britain was doing its utmost to put a stop to 
the Italian invasion and that black labourers could help by observing the law and keeping order. However, just one week after this pronouncement, rumours abounded that Italian doctors were poisoning black children in Georgetown and near the east coast of Demerara (Governor of British Guiana 1935c). A similar episode had recently happened in Jamaica, and the Governor, judging the mood to be incendiary, requested a warship to patrol the coast (Governor of British Guiana 1935d).

A few episodes from the rural uprisings in East Coast Demerara are of great interest to recount. In a report to the secretary of the Governor, the inspectorgeneral of police testified that two overseers had been assaulted, compelled to carry red flags and forced to march with strikers on the sugar estates (InspectorGeneral of Police 1935: 2). While rumours of communist infiltration always accompanied peasant uprisings in the 1930s Caribbean, this flag should not be confused with the hammer and sickle. Red is the spiritual colour of Africa in many Caribbean faiths. In Trinidad, the colour of Shango - the agency of thunder and lightning - is red. And, for the converted faith in St Vincent, red is the colour of Africa (Pollack-Eltz 1993: 17; Zane 1999: 84). In Guyana Comfa, red also represents Africa, as well as St Judas (the patron saint of desperate causes, we might also call him 'old John'), Leo (one of Haile Selassie I's title is Moa Anbessa, the Conquering Lion) and love (Is it red Frantz's secret colour?) (Gibson 2001: 85).

Another estate driver, providing evidencelater at a labour disputes commission, recounted how a field labourer had tried to force him to perform an 'African war dance' as drums were played. And in another incident, the overseer discovered that twenty strikers were blocking a bridge to the fields: 'One fellow laid down and said he was an Abyssinian General. He defied anybody to cross and said he meant to chop anyone who tried to do so' (Labour Disputes Commission 1936). The Chair of the commission asked the driver what he supposed was to be gained from these actions; the overseer replied, 'I suppose they thought that with the Abyssinia war on they would have a war too; in fact, that is what some of them said' (Labour Disputes Commission 1936).

I am an Abyssinian general. 
Robbie Shilliam - 9781526101037 Downloaded from manchesterhive.com at $04 / 26 / 2023$ 12:22:21PM via free access 